\title{
Intake and digestibility in cattle fed low-quality tropical forage and supplemented with nitrogenous compounds ${ }^{1}$
}

\author{
Isis Lazzarini², Edenio Detmann ${ }^{3}$, Cláudia Batista Sampaio², Mário Fonseca Paulino3 \\ Sebastião de Campos Valadares Filho ${ }^{3}$, Marjorrie Augusto de Souza ${ }^{2}$, Fabrício Albani \\ Oliveira ${ }^{4}$
}

\author{
1 Projeto financiado pelo CNPq com apoio da FAPEMIG (Programa Pesquisador Mineiro). \\ 2 Programa de Pós-Graduação em Zootecnia, Departamento de Zootecnia, Universidade Federal de Viçosa, Viçosa-MG, CEP: 36571 -000. \\ ${ }^{3}$ Departamento de Zootecnia, UFV. Pesquisador do CNPq. \\ ${ }^{4}$ Curso de Medicina Veterinária, UFV, Viçosa-MG, CEP: 36571-000.
}

\begin{abstract}
The objective of this study was to evaluate the effects of supplementation with nitrogenous compounds on intake, digestibility, and rumen microbial synthesis in cattle fed low-quality tropical forage. Five crossbred heifers, averaging $209 \mathrm{~kg}$ and fitted with ruminal fistulla, were used. The animals were fed ad libitum with signal grass (Brachiaria decumbens Stapf.) hay, which had crude protein (CP) content of 5.08\%, as dry matter (DM) basis. The five treatments were defined according to the increasing level of $\mathrm{CP}$ in the diet $(0,3,5,7$, and 9 percentile points above the forage CP level). The supplement consisted of the following nitrogen sources: urea, ammonium sulfate and albumin (4.5:0.5:1.0, respectively). The experiment was carried out according to a $5 \times 5$ Latin square design, with five experimental periods. The average CP levels in the diets were: $5.28,8.08,9.82,11.87$, and $13.63 \%$ on DM basis. The intakes of DM, organic matter (OM), and neutral detergent fiber (NDF) showed a quadratic response according to CP levels in the diet, with maximum responses at $10.83 \%, 10.78 \%$, and $10.37 \%$ $\mathrm{CP}$, respectively. The digestibility coefficients of OM and NDF showed a linear-response-plateau response according to CP levels, with the plateau beginning (maximum response) at $7.93 \%$ and $7.55 \% \mathrm{CP}$, respectively. The average daily concentration of rumen ammonia nitrogen (RAN) was positively related with CP levels. The RAN estimate associated with the maximum DM intake was $15.33 \mathrm{mg} / \mathrm{dL}$. It was observed that intestinal flow of microbial nitrogenous compounds and nitrogen intake became equivalent to each other at $7.13 \%$ of $\mathrm{CP}$.
\end{abstract}

Key Words: Brachiaria decumbens, microbial protein synthesis, rumen ammonia nitrogen, supplementation

\section{Consumo e digestibilidade em bovinos alimentados com forragem tropical de baixa qualidade e suplementados com compostos nitrogenados}

RESUMO - Objetivou-se avaliar os efeitos de compostos nitrogenados suplementares sobre o consumo, a digestibilidade e a síntese de proteína microbiana em bovinos alimentados com forragem tropical de baixa qualidade. Foram utilizadas cinco novilhas mestiças Holandês $\times$ Zebu, com peso vivo médio de $209 \mathrm{~kg}$, fistuladas no rúmen. O volumoso consistiu de feno de capim-braquiária (Brachiaria decumbens Stapf.) (5,08\% de proteína bruta (PB), com base na matéria seca), fornecido à vontade. Os cinco tratamentos avaliados foram definidos de acordo com o nível de suplementação proteica (0, 3, 5, 7 e 9 pontos percentuais acima do nível de PB da forragem). Como fonte de compostos nitrogenados, empregou-se mistura de ureia, sulfato de amônia e albumina, nas proporções de 4,5:0,5:1,0, respectivamente. O experimento constou de cinco períodos experimentais, segundo delineamento em quadrado latino $5 \times 5$. Os níveis médios de PB observados nas dietas foram de 5,28; 8,08; 9,82; 11,87 e 13,63\%, com base na matéria seca (MS). Verificou-se efeito quadrático dos níveis de PB na dieta sobre os consumos de MS, matéria orgânica (MO) e fibra em detergente neutro (FDN) (kg/dia), com respostas máximas nos níveis de 10,83\%, 10,78\% e 10,37\% de PB, respectivamente. Os coeficientes de digestibilidade da MO e FDN apresentaram relação do tipo linear-response-plateau com os níveis de PB na dieta com início de platô (resposta máxima) em 7,93 e 7,55\% de PB, respectivamente. A concentração média diária de nitrogênio amoniacal ruminal apresentou comportamento linear crescente em função dos níveis de PB da dieta, com valor estimado de 15,33 mg/dL, equivalente ao máximo consumo de MS. A avaliação da relação entre consumo de nitrogênio e fluxo intestinal de nitrogênio microbiano indica que as estimativas dessas variáveis tornam-se equivalentes no nível de 7,13\% de PB na dieta.

Palavras-chave: Brachiaria decumbens, nitrogênio amoniacal ruminal, síntese de proteína microbiana, suplementação 


\section{Introduction}

Pasture is the main nutrient resource for cattle production in Brazil and stands out from other feed sources due to lower cost and practical utilization (Paulino et al., 2006). However, the fast growth of tropical grasses during rainy season leads to plant maturation, implying high contents of cell wall compounds. Thus, high-quality forage is available for a short period. Moreover, the change from rainy to dry season causes an abrupt fall in pasture production and digestibility and is the main limiting factor to animal production in the tropics (Leng, 1984).

Under these conditions the nutritional deficiencies are assumed to be multiple, but the nitrogenous compounds deficiency must be considered as priority, since this implies suboptimal rumen conditions that limit microbial activity, forage intake and digestibility, and animal performance.

Supplementation is the main strategy for avoiding these limitations and adjusting the nutritional imbalance in tropical pastures (Paulino et al., 2006). Supplementations endeavors to increase pasture utilization by optimizing digestion, increasing the rate of passage of indigestible residues and, as consequence, improve the total digestible nutrients (TDN) intake (Paulino et al., 2004).

A large part of the energy substrates from potentially degradable neutral detergent fiber (pdNDF) of low-quality forage is not used because there is a ruminal deficiency of enzymatic systems (Paulino et al., 2006; Detmann et al., 2009). In this way, nitrogen is the main limiting nutrient in low-quality forages and its supplementation must be assumed as priority under these feed conditions.

Nitrogen supplementation increases microbial activity (Satter \& Slyter, 1974) and improves intake and energy use from forage (Leng, 1990). These effects result from improvement in the rate and extension of pdNDF degradation, and decrease in the rumen fill effect (Costa et al, 2008). Nevertheless, it is necessary to define an equilibrium point between nitrogenous compounds supplementation and optimal pdNDF use (Paulino et al., 2006).

In this way, when defining supplement composition, the supplemental crude protein (CP) must be seen as two different pools. The first one must be defined to improve the use of energy substrates from forage (pdNDF), while the second pool should be defined based on the use of carbohydrates of the supplement and, if necessary, supply the protein deficit according to weight gain defined in the production system (Paulino et al., 2006; Sampaio, 2007).

It is known that nitrogen supplementation can contribute to the microbial population nutrition and improve the intake and digestibility of low-quality forage. However, it is necessary to accurately quantify the actual benefits of nitrogen supplementation when production is based on low-quality tropical forage. This information could provide knowledge about optimizing supplement utilization.

The objective of this study was to evaluate the effects of supplemental nitrogenous compounds on intake, digestibility, and microbial protein synthesis in cattle fed low-quality tropical forage.

\section{Material and Methods}

The experiment was carried out in the Laboratório de Animais at the Departamento de Zootecnia of the Universidade Federal de Viçosa (UFV), Brazil.

Five crossbred heifers (Holstein $\times$ Gir), fitted with ruminal fistula and averaging $209 \pm 13 \mathrm{~kg}$ body weight (BW), were used. The animals were kept in individual stalls. Water and mineral mixture were available to the heifers at all time.

The forage fed to the animals consisted of low quality signal grass (Brachiaria decumbens Stapf.) hay, with average $5.08 \%$ CP on a dry matter (DM) basis.

The experiment consisted of five 16-day experimental periods. The first five days of each experimental period were used for the adaptation of the animals to the supplementation levels.

The five treatments assessed were set in order to raise the CP level of the diet to 0, 3, 5, 7 and 9 percentile points above the CP level of the forage, on DM basis. A mixture of urea, ammonium sulfate and albumin was used as a source of nitrogenous compounds, at the ratios of 4.5:0.5:1.0, respectively. These supplements were calculated based on the DM intake computed on the previous day and placed directly in the rumen of the animals.

The supplement ingredients were chosen based on their carbohydrate absence, so supplementation effects with nitrogenous compounds could be evaluated without any supplementary source of fiber or energy interfering in the measurements. Albumin was included in the supplement to meet the microbial requirements of true degradable protein, allowing the supply of essential substrates, such as branched chain volatile fatty acids.

The forage was supplied ad libitum, allowing approximately $10 \%$ in orts and fed twice a day, in equal portions, at 8 a.m. and 4 p.m. The supplements, in two portions of equal weight, were placed in the rumen of the animals when the forage was offered. The forage offered and the orts were quantified daily. 
For the quantification of voluntary intake, feed supplied between the sixth and the ninth days of each experimental period were considered and the orts were considered between the seventh and tenth day.

Forage and orts samples were processed in a Wiley mill (1-mm) and stored for later analysis.

The digestibility coefficients were estimated from fecal samples taken directly from the rectum of the animals from the seventh to the tenth day in each experimental period according to the following distribution: 7 th day -6 a.m. and 2 p.m.; 8th day -8 a.m. and 4 p.m.; 9th day -10 a.m. and 6 p.m.; and 10 th day -12 p.m. and 8 p.m. The feces samples were oven dried $\left(60^{\circ} \mathrm{C} / 72\right.$ hours $)$ and processed in a Wiley mill (1-mm). Composite samples were elaborated per animal and experimental period.

To evaluate the rumen $\mathrm{pH}$ and rumen ammonia nitrogen (RAN) concentration, samples of rumen fluid were taken on the sixth day of each experimental period at 4 a.m., 8 a.m., 12 p.m., 4 p.m., 8 p.m. and 12 a.m. The samples were collected manually from the liquid:solid interface of the rumen mat, filtered through a triple layer of cheesecloth and submitted to $\mathrm{pH}$ assessment by using a digital potentiometer. A $40 \mathrm{~mL}$ aliquot was then separated, fixed with $1 \mathrm{~mL} \mathrm{H}_{2} \mathrm{SO}_{4}$ $(1: 1)$ and frozen $\left(-20^{\circ} \mathrm{C}\right)$ for later analysis.

Rumen microorganisms were isolated on the 10th day of each experimental period. Samples of rumen contents were taken immediately before and six hours after morning feeding according to Cecava et al. (1990).

On the 12th, 14th and 16th days of each experimental period urine spot samples were obtained, approximately four hours after the morning feeding. The samples were filtered through cheesecloth and a $10 \mathrm{~mL}$ aliquot was separated and diluted with $40 \mathrm{~mL} \mathrm{H}_{2} \mathrm{SO}_{4}(0.036 \mathrm{~N})$.

The samples of feeds, orts and faeces were analyzed for $\mathrm{DM}$, organic matter $(\mathrm{OM}), \mathrm{CP}$, ether extract (EE), acid detergent fiber (ADF), and lignin $\left(\mathrm{H}_{2} \mathrm{SO}_{4} 72 \% \mathrm{w} / \mathrm{w}\right)$ contents according to Silva \& Queiroz (2002). In the neutral detergent fiber (NDF) analysis, the samples were treated with a heat stable alpha amylase, without using sodium sulphite and corrected for residual ash (Mertens, 2002). Neutral detergent fibre was also corrected for nitrogenous compounds content and the ADIP content was estimated as described by Licitra et al. (1996). Supplement samples were analyzed regarding DM, OM, and CP as described above (Table 1).

Fecal excretion was estimated by using the indigestible NDF (iNDF) as internal marker. The iNDF contents in forage, orts and feces were obtained by a 144 hours in situ rumen incubation procedure using non-woven textile bags $\left(100 \mathrm{~g} / \mathrm{cm}^{2}\right)$. Potentially digestible NDF was
Table 1 - Chemical composition of hay and supplement

\begin{tabular}{lrc}
\hline Item $^{1}$ & Hay & Supplement \\
\hline DM $(\%$ as fed) & 87.74 & 96.70 \\
OM (\% DM) & 94.35 & 98.75 \\
CP (\% DM) & 5.08 & 235.34 \\
EE (\% DM) & 0.62 & - \\
NDF (\% DM) & 83.55 & - \\
NDFom(n) (\% DM) & 79.73 & - \\
NFC (\% DM) & 8.92 & - \\
ADFom(n) (\% DM) & 46.43 & - \\
Lignin (\% DM) & 7.51 & - \\
ADIP (\% CP) & 24.46 & -
\end{tabular}

${ }^{1} \mathrm{DM}=$ dry matter; $\mathrm{OM}=$ organic matter; $\mathrm{CP}=$ crude protein; $\mathrm{EE}=$ ether extract; $\mathrm{NDF}=$ neutral detergent fiber; $\operatorname{NDFom}(\mathrm{n})=$ neutral detergent fiber corrected for ash and nitrogenous compounds; NFC = non-fibrous carbohydrates; $\operatorname{ADFom}(\mathrm{n})=$ acid detergent fiber corrected for ash and nitrogenous compounds. $\mathrm{ADIP}=$ acid detergent insoluble protein. ${ }^{2} \mathrm{NFC}=\mathrm{OM}-[\mathrm{CP}+\mathrm{EE}+\mathrm{NDFom}(\mathrm{n})]$.

defined as the difference between the NDF corrected for ash and nitrogenous compounds [aNDFom(n)] and iNDF.

The RAN content in rumen fluid samples was evaluated by the micro-Kjeldahl system, without acid digestion and after distillation with potassium hydroxide $(2 \mathrm{~N})$, after previous centrifugation of the sample to $1,000 \times g$, for $15 \mathrm{~min}$. The concentrations obtained at the different sampling times were combined by animal and period in order to obtain a single value that represented the average daily RAN concentration. Rumen $\mathrm{pH}$ values were combined in a similar way.

The rumen microorganism samples were oven dried $\left(60^{\circ} \mathrm{C}\right)$ and assessed for DM, CP (Silva \& Queiroz, 2002), and purine bases (Ushida et al., 1985) contents.

The urine samples, after thawing, were composed per animal and experimental period. The concentrations of uric acid and creatinine were obtained by colorimetric enzymatic (Bioclin K052) and modified Jaffé (Bioclin K016-1) methods, respectively. The contents of allantoin were estimated according to Chen \& Gomes (1992).

The total urinary volume was estimated by the ratio of creatinine concentration in the urine on its excretion per unit of live weight, which was estimated according to the following equation (Chizzotti et al., 2006):

$$
C E=32.27-0.01093 \times B W
$$

where CE is the daily creatinine excretion ( $\mathrm{mg} / \mathrm{kg}$ of $\mathrm{BW}$ ); and BW the live weight $(\mathrm{kg})$.

Purine derivatives excretion was calculated by the sum of the amounts of allantoin and uric acid excreted in the urine. The absorbed purines were calculated from purine derivatives excretion by the equation (Verbic et al., 1990):

$$
A P=\frac{P D-0.385 \times B W^{0.75}}{0.85}
$$


where AP is the absorbed purines ( $\mathrm{mmol} / \mathrm{d}$ ); PD the purine derivatives excretion (mmol/d); 0.85 the recovery of absorbed purines as purine derivatives in the urine ( $\mathrm{mmol} / \mathrm{mmol}$ ); and 0.385 the endogenous purine derivatives excretion in the urine $\left(\mathrm{mmol} / \mathrm{BW}^{0.75}\right)$.

The microbial synthesis of nitrogenous compounds in the rumen was estimated as function of the absorbed purines and the $\mathrm{N}_{\mathrm{RNA}}: \mathrm{N}_{\text {TOTAL }}$ ratio in the microorganisms (Chen \& Gomes, 1992):

$$
N M I C=\frac{70 \times A P}{0.83 \times R \times 1000}
$$

where NMIC is the microbial nitrogen flow in the small intestine $(\mathrm{g} / \mathrm{d})$; $\mathrm{R}$ the $\mathrm{N}_{\mathrm{RNA}}: \mathrm{N}_{\text {TOTAL }}$ ratio in the microorganisms ( $\mathrm{mg} / \mathrm{mg}$ ); 70 the nitrogen contents in purines $(\mathrm{mg} / \mathrm{mmol})$; and 0.83 the intestinal digestibility of the microbial purines (mg/mg).

The experimental design was a $5 \times 5$ Latin square with five animals and five experimental periods. The actual average diet content of CP at each level of supplementation was used as independent variable for interpretation of the treatment effects.

An orthogonal partition of the treatments sum of squares into linear, quadratic, cubic, and fourth degree effects was performed subsequent to the analysis of variance and a linear regression model was then fitted. All the statistical procedures were carried out using SAS (Statistical Analysis System) $(\alpha=0.10)$.

\section{Results and Discussion}

The average CP levels in the diets, which were calculated as the ratio of the total CP intake (forage and supplement) on the total DM intake, were 5.28, 8.08, 9.82, 11.87 and $13.63 \%$, on DM basis, for the supplementation levels of 0 , 3, 5, 7 and 9 percentile points, respectively.

A quadratic effect $(\mathrm{P}<0.10)$ of the $\mathrm{CP}$ levels in the diet on the DM, OM, and NDF intakes $(\mathrm{kg} / \mathrm{d})$ was detected, with critical points (maximum response) at the CP levels of $10.83,10.78$ and $10.37 \%$ CP, respectively (Table 2). On the other hand, the intake of $\mathrm{CP}$ increased linearly $(\mathrm{P}>0.10)$ and NFC intake decreased linearly $(\mathrm{P}<0.10)$ as the CP levels in the diet increased (Table 2). The NFC intake pattern seemed to be caused by decreasing NFC levels in the diet as nitrogen supplementation increased.

The pattern of DM, OM, and NDF intakes, when expressed as $\mathrm{g} / \mathrm{kg}$ of $\mathrm{BW}$, was linear as function of $\mathrm{CP}$ levels in the diet $(\mathrm{P}<0.10)$. This performance apparently contradicts the patterns observed on intake estimates expressed as $\mathrm{kg} / \mathrm{d}$. Nevertheless, the descriptive pattern of least squares means indicates decrease in intake at the highest CP level (13.63\%). This fact, associated with the low

Table 2 - Least squares means, coefficients of variation (CV), and significance of effects for voluntary intake according to crude protein levels in the diet

\begin{tabular}{|c|c|c|c|c|c|c|c|c|c|c|}
\hline \multirow[b]{2}{*}{ Item $^{3}$} & \multicolumn{5}{|c|}{ Crude protein level (\%) } & \multirow[b]{2}{*}{ CV (\%) } & \multicolumn{4}{|c|}{ Effect $^{12}$} \\
\hline & 5.28 & 8.08 & 9.82 & 11.87 & 13.63 & & $\mathrm{~L}$ & $\mathrm{Q}$ & $\mathrm{C}$ & $\mathrm{F}$ \\
\hline & \multicolumn{10}{|c|}{$\mathrm{kg} / \mathrm{d}$} \\
\hline $\mathrm{DM}^{4}$ & 3.383 & 3.891 & 4.069 & 4.269 & 3.870 & 12.8 & $*$ & $*$ & ns & ns \\
\hline $\mathrm{OM}^{5}$ & 3.193 & 3.683 & 3.842 & 4.028 & 3.645 & 13.1 & $*$ & $*$ & ns & ns \\
\hline$C P^{6}$ & 0.179 & 0.312 & 0.399 & 0.507 & 0.530 & 17.6 & $* * *$ & ns & ns & ns \\
\hline $\mathrm{EE}^{7}$ & 0.020 & 0.023 & 0.024 & 0.024 & 0.022 & 14.0 & ns & $* *$ & ns & ns \\
\hline $\operatorname{NDFom}(n)^{8}$ & 2.698 & 3.083 & 3.171 & 3.291 & 2.948 & 12.9 & ns & $*$ & ns & ns \\
\hline $\mathrm{NFC}^{9}$ & 0.296 & 0.265 & 0.248 & 0.207 & 0.145 & 20.0 & $* * *$ & ns & ns & ns \\
\hline $\mathrm{DDM}^{10}$ & 1.360 & 1.752 & 1.842 & 2.031 & 1.887 & 15.7 & $* * *$ & $*$ & ns & ns \\
\hline $\mathrm{DOM}^{11}$ & 1.348 & 1.746 & 1.836 & 1.991 & 1.833 & 16.0 & $* * *$ & $*$ & ns & ns \\
\hline $\mathrm{DNDF}^{12}$ & 1.305 & 1.674 & 1.714 & 1.830 & 1.657 & 16.2 & $* *$ & * & ns & ns \\
\hline $\mathrm{TDN}^{13}$ & 1.348 & 1.758 & 1.850 & 1.999 & 1.843 & 15.8 & $* * *$ & * & ns & ns \\
\hline \multirow[t]{2}{*}{$\mathrm{iNDF}^{14}$} & 1.000 & 1.192 & 1.236 & 1.241 & 1.113 & 13.3 & ns & $* *$ & ns & ns \\
\hline & \multicolumn{10}{|c|}{ g/kg body weight } \\
\hline $\mathrm{DM}^{15}$ & 14.97 & 18.16 & 19.32 & 20.37 & 19.00 & 14.1 & $* *$ & ns & ns & ns \\
\hline $\mathrm{OM}^{16}$ & 14.10 & 17.18 & 18.26 & 19.21 & 17.90 & 14.4 & $* *$ & ns & ns & ns \\
\hline $\operatorname{NDFom}(n)^{17}$ & 11.93 & 14.39 & 15.09 & 15.69 & 14.50 & 14.1 & $*$ & ns & ns & ns \\
\hline $\mathrm{TDN}^{18}$ & 5.67 & 8.36 & 8.58 & 9.51 & 9.10 & 16.5 & $* * *$ & $*$ & ns & ns \\
\hline \multicolumn{11}{|c|}{ 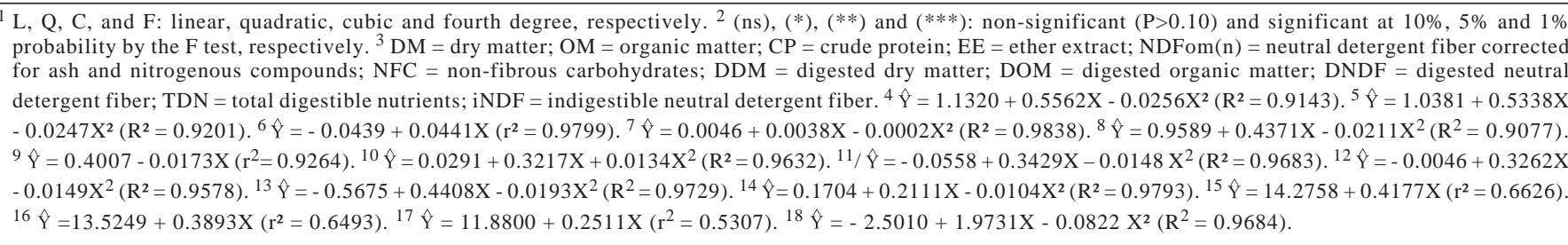 } \\
\hline
\end{tabular}


coefficients of determination (Table 2), could indicate that quadratic responses were obtained, even though no significant second degree effects were observed $(\mathrm{P}>0.10)$. Thus, a descriptive adjustment of second degree equations was made, which indicated critical points (maximum response) at the CP levels of $11.65 \%\left(\mathrm{R}^{2}=0.9641\right), 11.56 \%$ $\left(\mathrm{R}^{2}=0.9660\right)$, and $10.97 \%\left(\mathrm{R}^{2}=0.9625\right)$ for $\mathrm{DM}, \mathrm{OM}$, and NDF intakes (g/kg BW), respectively.

Actually, the TDN intake showed a quadratic pattern ( $\mathrm{P}<0.10)$ according to the $\mathrm{CP}$ levels in the diet, with critical points (maximum response) at $11.44 \%(\mathrm{~kg} / \mathrm{d})$ and $12.00 \%$ (g/kg BW) (Table 2).

In general, the supplemental nitrogenous compounds caused increase in the voluntary intake up to limits of $11 \%$ $\mathrm{CP}$ in the diet. This pattern reinforced the great importance of supplementation with nitrogen for animals fed lowquality tropical forages, mainly during the dry season of the year, when the energy extraction from fibrous carbohydrates is limited by deficiency of nitrogenous compounds for microbial synthesis of enzymatic systems (Leng, 1990; Paulino et al., 2006; Detmann et al., 2009).

Sampaio (2007) supplemented cattle fed low-quality tropical forage with nitrogenous compounds and observed increase in intake up to limits of $10 \% \mathrm{CP}$, which agrees with the results obtained in this study.

Increases in voluntary forage intake due to nitrogen supplementation are associated with a sequence of events, such as increases in microbial growth rate and efficiency, DM digestion rate and passage rate of resident mass in the rumen (Nocek \& Russell, 1988).

As a consequence of increase in rumen degradation, increase in the output of indigestible fiber and in the rumen turnover would be observed (Allen, 1996). At same time as the rate of passage increased (or the output of indigestible fiber increased), there would be increase in the voluntary intake of low-quality forages.

The positive effects of nitrogenous compounds supplementation on ruminal transit were brought into evidence through iNDF intake (Table 2), which showed a quadratic profile $(\mathrm{P}<0.10)$ with maximum response at $10.20 \%$ CP.

Increases in voluntary intake as a function of supplementation with nitrogenous compounds were also observed by Hannah et al. (1991), Mathis et al. (2001), Köster et al. (2002), and Ortiz-Rubio et al. (2007) in cattle fed low-quality forage.

Conversely, reductions in voluntary intake were reported at CP levels higher than $11 \%$ (Table 2). This fall may be justified, at least in part, by the possible occurrence of protein excess for the microbial/animal metabolism.

Protein in excess implies greater urea synthesis in the liver, lower net/metabolizable energy ratio, and higher body heat formation (NCR, 1988). According to Poppi \& McLennan (1995), heat dissipation is a great limitation to cattle production in the tropics. Even when the animals do not demonstrate the obvious symptoms of heat stress, their intake is restricted, as a way to reduce the metabolism and adjust body heat production to rates at which it can be comfortably dissipated.

In addition, excess circulating ammonia in the blood can lead to a situation of poor brain tissue functioning due to energy deficit, causing discomfort to the animals and resulting in a reduction in voluntary intake as a mechanism to reduce the indisposition (Detmann et al., 2007).

The union of these assumptions could lead to infer that decreases in voluntary intake could be observed when animals are supplemented with excess of CP. Del Curto et al. (1990a; 1990b) and Sampaio (2007) also observed decreases in voluntary intake associated with excess of supplemental nitrogen.

The EE digestibility coefficient was not affected by CP levels in the diet $(\mathrm{P}<0.10)$. On other hand, the DM digestibility coefficient showed a positive linear relationship with CP levels $(\mathrm{P}<0.10)$ (Table 3$)$. The digestibility coefficients of CP, pdNDF, and NFC had a quadratic pattern according to increase in $\mathrm{CP}$ levels in the diet $(\mathrm{P}<0.10)$. Cubic profiles were observed for the $\mathrm{OM}$ and NDF digestibility coefficients, and for TDN levels in the diet $(\mathrm{P}<0.10)$ (Table 3).

The CP digestibility pattern seems to directly reflect the increase in supply of highly degradable nitrogenous compounds in the diet (Table 3). On the other hand, the decrease in the NFC digestibility according to increase in $\mathrm{CP}$ diet levels seems to be associated with the linear reduction in NFC intake (Table 2). The negative estimates of this parameter were probably observed because intake was lower than metabolic NFC present in the fecal mass (Detmann et al., 2006a).

Biological responses with a cubic pattern are not normally observed. However, the least squares means of the OM and NDF digestibility coefficients and the TDN levels in the diet tended to stabilize at the higher CP levels (Table 3), which agreed with a linear-reponseplateau (LRP) profile and thus new equations were adjusted (Figure 1).

Linear increases in the estimates were observed up to limits close to $7 \%$ CP $(\mathrm{P}<0.10)$. From this point the values were unchanged (Figure 1). It must be emphasized that NDF 
Table 3 - Least squares means, coefficients of variation (CV), and significance of effects for digestibility coefficients and total digestible nutrients levels according to the crude protein levels in the diet

\begin{tabular}{|c|c|c|c|c|c|c|c|c|c|c|}
\hline \multirow[b]{2}{*}{ Item $^{3}$} & \multicolumn{5}{|c|}{ Crude protein level (\%) } & \multirow[b]{2}{*}{$\mathrm{CV}(\%)$} & \multicolumn{4}{|c|}{ Effec $^{12}$} \\
\hline & 5.28 & 8.08 & 9.82 & 11.87 & 13.63 & & $\mathrm{~L}$ & $\mathrm{Q}$ & $\mathrm{C}$ & $\mathrm{F}$ \\
\hline $\mathrm{DM}^{2}$ & 41.41 & 46.61 & 44.95 & 47.05 & 48.04 & 5.0 & $* * *$ & ns & ns & ns \\
\hline $\mathrm{OM}^{3}$ & 43.20 & 48.97 & 47.43 & 48.89 & 49.64 & 4.2 & $* * *$ & $*$ & $*$ & ns \\
\hline $\mathrm{CP}^{4}$ & 32.22 & 55.63 & 62.20 & 69.72 & 74.10 & 12.8 & $* * *$ & $* *$ & ns & ns \\
\hline $\mathrm{EE}$ & -3.47 & 31.98 & 35.99 & 30.00 & 36.24 & 128.8 & ns & ns & ns & ns \\
\hline $\operatorname{NDFom}(n)^{5}$ & 46.94 & 53.62 & 51.25 & 52.54 & 53.26 & 5.2 & $* * *$ & $*$ & $*$ & ns \\
\hline $\mathrm{NFC}^{6}$ & 13.19 & -17.66 & -28.83 & -71.29 & 161.50 & 83.2 & $* * *$ & $* *$ & ns & ns \\
\hline $\operatorname{pdNDF}^{7}$ & 75.04 & 86.39 & 84.27 & 85.29 & 86.44 & 5.3 & $* * *$ & $* *$ & ns & ns \\
\hline $\mathrm{TDN}^{8}$ & 40.70 & 46.56 & 45.05 & 46.31 & 47.05 & 4.3 & $* * *$ & $* *$ & $*$ & ns \\
\hline
\end{tabular}

${ }^{1} \mathrm{~L}, \mathrm{Q}, \mathrm{C}$, and F: linear, quadratic, cubic and fourth degree, respectively. ${ }^{2}(\mathrm{~ns}),(*),(* *)$ and $(* * *)$ : non-significant (P>0.10) and significant at $10 \%, 5 \%$ and $1 \%$ probability by the F test, respectively. ${ }^{3} \mathrm{DM}=$ dry matter; $\mathrm{OM}=$ organic matter; $\mathrm{CP}=$ crude protein; $\mathrm{EE}=$ ether extract; $\mathrm{NDF}$ (n) $(\mathrm{n})=$ neutral detergent fiber correct for ash and nitrogenous compounds; NFC = non-fibrous carbohydrates; pdNDF = potentially degradable neutral detergent fiber; TDN = total digestible nutrients ${ }^{2} \hat{Y}=38,8169+0,69819 X\left(r^{2}=0,7622\right) .{ }^{3} \hat{Y}=-5.91946+16.5447 X-1.6562 X^{2}+0.0545 X^{3}\left(R^{2}=0.9322\right) .{ }^{4} \hat{Y}=-27.7261+13.9954 X-0.4819 X^{2}\left(R^{2}=0.9951\right)$ ${ }^{5} \hat{Y}=-16.0780+21.4857 X-2.1865 X^{2}+0.0723 X^{3}\left(R^{2}=0.9052\right) .{ }^{6} \hat{Y}=-119.0186+38.5258 X-3.0108 X^{2}\left(R^{2}=0.9690\right) .{ }^{7} \hat{Y}=49.6123+6.4713 X-0.2821 X^{2}$ $\left(R^{2}=0.8368\right) .{ }^{8} \hat{Y}=-10.2436+17.1688 X-1.7193 X^{2}+0.0564 X^{3}\left(R^{2}=0.9387\right)$.
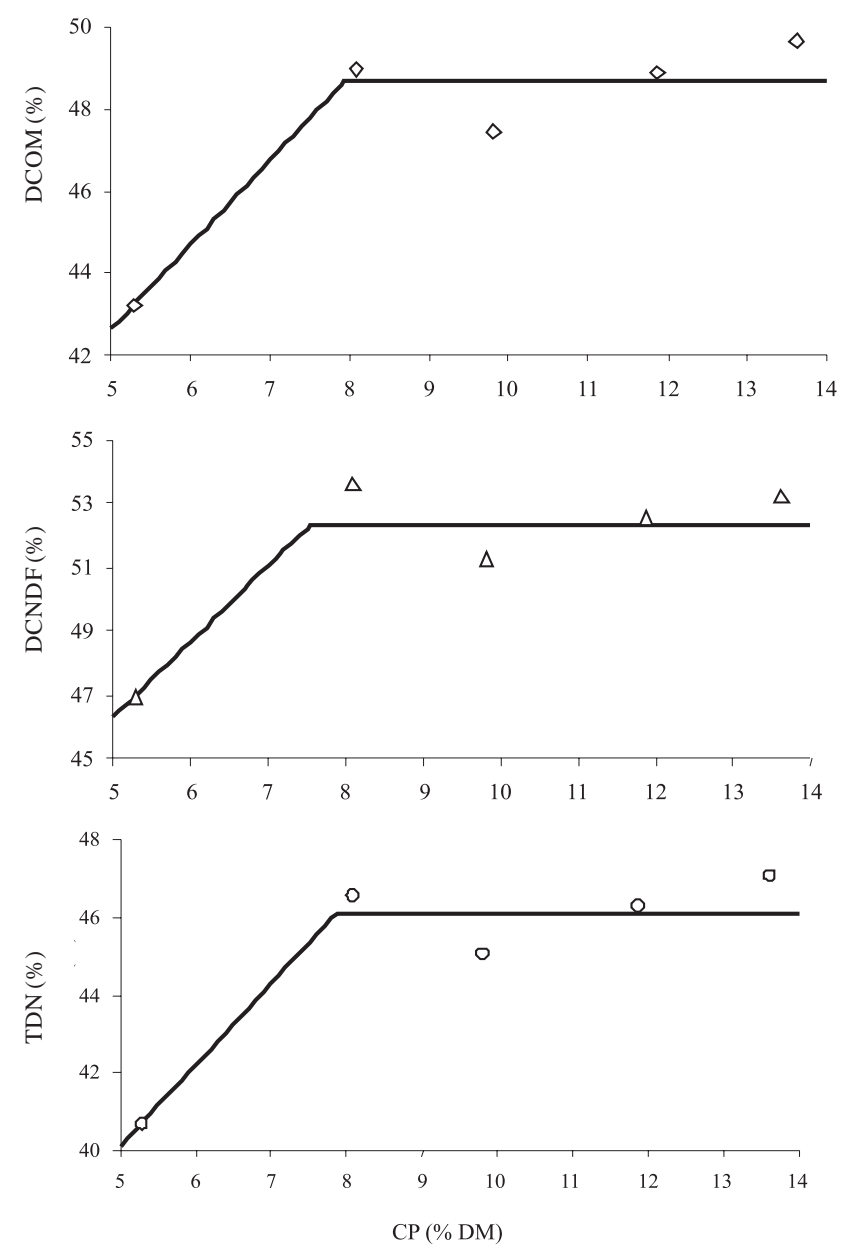

Figure 1 - Relationship between the crude protein (CP) level in the diet and estimates of organic matter digestibility coefficient (DCOM) $(\hat{\mathrm{Y}}=32.3194+2.0610 \mathrm{X} ; \forall \mathrm{X} \leq 7.9263$; $\left.\hat{\mathrm{Y}}=48.6533 ; \forall \mathrm{X}>7.9263 ; \mathrm{R}^{2}=0.9067\right)$, neutral detergent fiber digestibility coefficient (DCNDF) $(\hat{\mathrm{Y}}=34.3434+2.3860 \mathrm{X} ; \forall \mathrm{X} \leq 7.5477 ; \hat{\mathrm{Y}}=52.3500$; $\left.\forall \mathrm{X}>7.5477 ; \mathrm{R}^{2}=0.9298\right)$, and total digestible nutrients (TDN) level in the diet $(\hat{Y}=29.6497+2.0930 X$; $\left.\forall \mathrm{X} \leq 7.8777 ; \hat{\mathrm{Y}}=46.1367 ; \forall \mathrm{X}>7.8777 ; \mathrm{R}^{2}=0.9236\right)$. is the main compound in all diets from a quantitative point of view. Thereby, the OM digestibility pattern and the TDN level only reflected the NDF digestibility.

Crude protein levels in the diet of 6-8\%, as DM basis, are necessary to supply the microbial requirements of nitrogenous compounds. At lower CP levels, the digestibility falls off (Van Soest, 1994). This kind of constraint is mainly observed in fibrous carbohydrate use (Sampaio et al., 2009). Thus, it can be inferred that CP diet levels close to 7\% are required for adequate NDF use from low-quality basal forage (Figure 1).

The measurement of the intake of digested compounds allows the integration of the effects of supplementation on intake and digestibility (Sampaio, 2007). In this context, a quadratic effect of the CP levels was observed on the intake of digested DM, digested OM, and digested NDF $(\mathrm{P}<0.10)$, with critical points (maximum response) at 11.97,

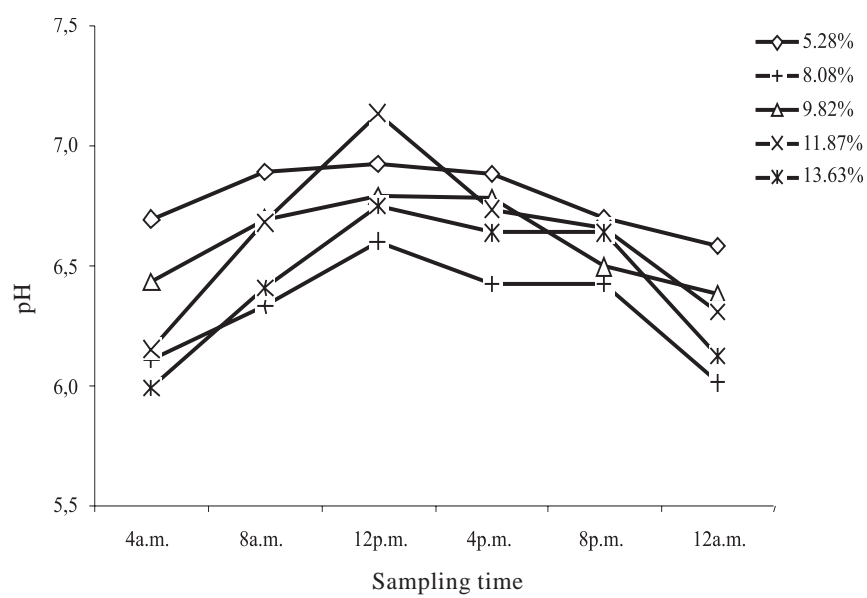

Figure 2 - Average values of rumen $\mathrm{pH}$ according to the crude protein level in the diet and sampling time. 
Table 4 - Least squares means, coefficients of variation (CV), and significance of effects for rumen pH and characteristics of the nitrogenous compounds metabolism according to the crude protein levels in the diet

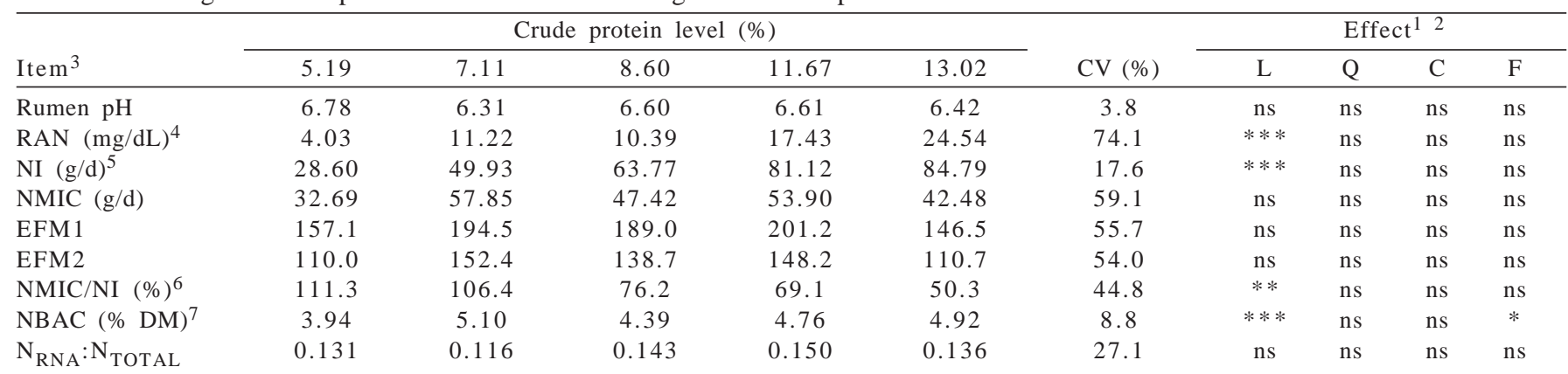

${ }^{1} \mathrm{~L}, \mathrm{Q}, \mathrm{C}$, and F: linear, quadratic, cubic and fourth degree, respectively. ${ }^{2}(\mathrm{~ns}),(*),(* *)$ and $(* * *)$ : non-significant $(\mathrm{P}>0.10)$ and significant at $10 \%, 5 \%$ and $1 \%$ probability by the $\mathrm{F}$ test, respectively. ${ }^{3} \mathrm{RAN}=$ rumen ammonia nitrogen; NI = nitrogen intake; NMIC = microbial nitrogen flow in the small intestine; EFM1 = efficiency of microbial synthesis (g microbial CP/kg TDN); EFM2 = efficiency of microbial synthesis based on true digestibility (g microbial CP/kg of true TDN); NBAC = nitrogen content in rumen microorganisms; $\mathrm{N}_{\mathrm{RNA}}: \mathrm{N}_{\mathrm{TOTAL}}=$ ratio of purine nitrogen on total nitrogen in the rumen microorganisms. ${ }^{4} \hat{\mathrm{Y}}=-7.3945+2.0980 \mathrm{X}$ $\left(r^{2}=0.9209\right) .{ }^{5} \hat{Y}=-7.0240+7.0560 X\left(r^{2}=0.9799\right) .{ }^{6} \hat{Y}=151.6370-7.2724 X\left(r^{2}=0.9762\right) .{ }^{7} \hat{Y}=-65.6248+31.3941 X-5.0381 X^{2}+0.3463 X^{3}-0.0086 X^{4}\left(R^{2}=1.0000\right)$.

11.55 , and $10.96 \% \mathrm{CP}$, respectively (Table 2 ). These results agreed with the DM and TDN intakes (Table 2) and indicated that $\mathrm{CP}$ levels close to $11 \%$ are necessary to maximize the intake of digestible nutrients under low-quality forage feeding conditions.

Rumen pH was not affected by CP levels ( $\mathrm{P}>0.10)$ (Table 4) and the average values were found higher than the inhibitory critical limits for cellulolytic microorganisms (Hoover, 1986) at all sampling times (Figure 2). Therefore, there was no damage to ruminal fermentation associated with $\mathrm{pH}$.

The RAN concentration has been frequently applied to qualify rumen conditions for microbial activity, mainly for fiber degrading bacteria, which use ammonia as preferable source of nitrogenous compounds for growth (Russell et al., 1992). Deficient levels of NAR cause decrease in microbial growth directly as nitrogen requirements are not supplied, and indirectly, because there would be an increase in energy demands for nitrogen

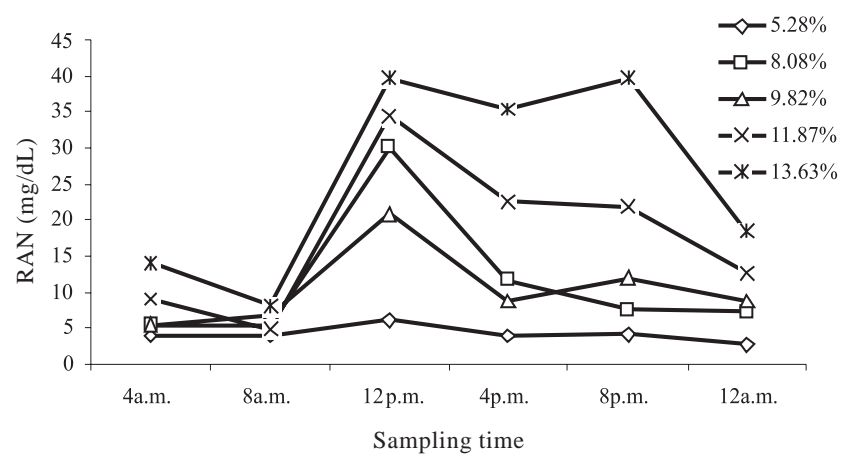

Figure 3 - Average values of rumen ammonia nitrogen (RAN) concentration according to the crude protein level in the diet and sampling time. assimilation (Wallace et al., 1997). Under these assumptions, it is possible to infer that the RAN concentration must be adequate to optimize microbial growth and fiber degradation.

The average daily RAN concentration (Table 4; Figure 3) showed a positive linear pattern according to the CP levels in the diet $(\mathrm{P}<0.10)$.

The NRC (1988) suggested 5 mg RAN/dL rumen fluid as the minimal concentration for efficient OM digestion in the rumen. On the other hand, Leng (1990) suggested 10 and $20 \mathrm{mg}$ RAN/dL for maximizing rumen digestion and voluntary intake under tropical conditions, respectively. However, Hoover (1986), in a broad literature review, reported optimal RAN levels for microbial growth and degradation of 6.2 and $21.4 \mathrm{mg} / \mathrm{dL}$ when the diets present CP levels higher and lower than 6\%, respectively.

These apparent contradictions in the interpretation of the optimal RAN level for ruminal degradation (mainly fibrous carbohydrates) seem to be based on variations in

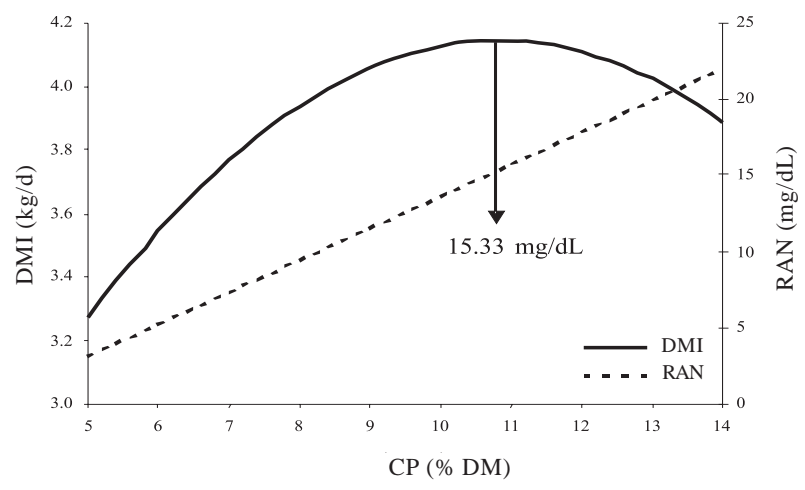

Figure 4 - Relationship between dry matter intake (DMI) and the rumen ammonia nitrogen (RAN) concentration according to the crude protein (CP) levels in the diet. 
the microbial requirements that are affected by basal substrate and rumen $\mathrm{pH}$, and on interactions between microbial species and degraded substrate (McAllan \& Smith, 1983; Hoover, 1986; Leng, 1990). It can establish some constraints to define an overall application of these references (Sampaio, 2007).

The evaluation of the relationship between forage intake and RAN concentration using their respective regression equations (Table 4) demonstrated that maximum intake occurred at $15.33 \mathrm{mg} \mathrm{NAR/dL}$ rumen fluid (Figure 4). This estimate was higher than those reported by OrtizRubio et al. (2007) and Sampaio (2007), who affirmed that RAN concentrations close to $10 \mathrm{mg} / \mathrm{dL}$ would be enough to maximize the intake of low-quality tropical forages.

The flow of microbial nitrogenous compounds in the small intestine (NMIC) was not affected by different CP levels in the diet ( $>>0.10)$ (Table 4), which apparently contradicted the arguments here presented about intake and digestibility, which are based on improvement of the rumen environment associated with increase in RAN concentration. However, better understanding of NMIC was obtained when it was evaluated together with the RAN and nitrogen intake (NI) (Table 4). It must be emphasized that NI was lower that NMIC at the lowest CP level in the diet (5.28\%) (Table 4). A similar pattern was reported by Sampaio (2007).

In this context, the evaluation of the NMIC ratio on NI using the regression equation as a function of CP levels in the diet indicated that estimates of these variables became equivalent to each other at 7.13\% CP (Table 4). This result shows that a great part of nitrogenous compounds demanded by rumen microorganisms could be attributed to urea recycling when diet CP levels were lower than $7.13 \%$, although this mechanism would be inefficient to sustain (Van Soest, 1994).

This result corroborated the pattern for the OM and NDF digestibility coefficients and indicated that CP levels close to $7 \%$ were required to sustain a microbial population that is capable of efficient use of fibrous carbohydrates from low-quality forages.

The $\mathrm{N}_{\mathrm{RNA}}$ : $\mathrm{N}_{\text {TOTAL }}$ ratio in the rumen microorganisms was not associated with $\mathrm{CP}$ levels in the $\operatorname{diet}(\mathrm{P}>0.10)$ and presented an average value of 0.135 (Table 4). On the other hand, the nitrogenous compounds content in microorganisms (NBAC) presented a fourth degree effect of $\mathrm{CP}$ levels $(\mathrm{P}<0.10)$. However, the evaluation of least squares means suggested a LRP pattern $(\hat{\mathrm{Y}}=1.7526+0.4140 \mathrm{X}$; $\left.\forall \mathrm{X} \leq 7.09 ; \hat{\mathrm{Y}}=4.6900 ; \forall \mathrm{X}>7.09 ; \mathrm{R}^{2}=0.8272\right)$, with the plateau beginning at $7.09 \% \mathrm{CP}$ (maximum estimate).
The microorganism composition is directly affected by their growing rate (White, 2000), which reflects the physical and chemical conditions of the growth environment. Under deficiency of nitrogenous compounds, intracellular carbohydrate accumulation is observed (Nocek \& Russell, 1988), which leads to a decrease in the nitrogenous compound contents.

Thus, it can be stated that the microbial growth rate was negatively affected at CP levels lower than 7\%, which caused alterations in microbial composition, once more corroborating the NDF digestibility pattern (Figure 1), as discussed previously.

No relationship ( $\mathrm{P}>0.10)$ was observed between $\mathrm{CP}$ levels in the diet and microbial synthesis efficiency (EFM1) that presented an average estimate of $177.7 \mathrm{~g}$ microbial $\mathrm{CP} / \mathrm{kg}$ TDN. This estimate was higher than the theoretical efficiency suggested by Valadares Filho et al. (2006) for tropical conditions (120 g microbial CP/kg TDN).

However, the intake of non-fibrous components of TDN could be considered low compared to normal feeding conditions (Table 2), increasing the relative contribution of fecal metabolic fractions and consequently resulting in low apparent digestibility coefficients, mainly for NFC (Table 3). From this point of view, the microbial synthesis efficiency was also expressed considering the true digestibility of non-fibrous compounds (EFM2) by using the fecal metabolic fractions $(\mathrm{kg} / \mathrm{d})$ reported by Detmann et al. (2006a; 2006b; 2006c) for growing cattle.

The average EFM2 estimate was 132.0 g microbial $\mathrm{CP} / \mathrm{kg}$ true TDN (Table 4). Although this value was higher than that suggested by Valadares Filho et al. (2006), it must be reported that deficiencies of nitrogenous compounds in the diet caused a net gain of nitrogen in the rumen through a higher representativeness of recycling events, that implied increase in microbial efficiency (NRC, 2001).

\section{Conclusions}

Supplementation with nitrogenous compounds in quantities that raise the crude protein content in the diet to levels close to $11 \%$ optimized the use of low quality tropical forage. At least $7 \%$ crude protein is necessary in the diet to sustain microbial growth and support efficient fibrous carbohydrate digestion of low-quality forages.

\section{Literature Cited}

ALLEN, M.S. Physical constrains on voluntary intake of forages by ruminants. Journal of Animal Science, v.74, p.3063-3075, 1996. 
CECAVA, J.M; MERCHEN, N.R.; GAY, L.C. et al. Composition of ruminal bacteria harvested from steers as influenced by dietary energy level, feeding frequency, and isolation techniques. Journal of Dairy Science, v.73, p.2480-2488, 1990.

CHEN, X.B.; GOMES, M.J. Estimation of microbial protein supply to sheep and cattle based on urinary excretion of purine derivatives-an overview of the technical details. Buchsburnd Aberdeen: Rowett Research Institute, 1992. 21p.

CHIZZOTTI, M.L.; VALADARES FILHO, S.C.; VALADARES, R.F.D. et al. Consumo, digestibilidade e excreção de uréia e derivados de purinas em novilhas de diferentes pesos. Revista Brasileira de Zootecnia, v.35, p.1813-1821, 2006.

COSTA, V.A.C.; DETMANN, E.; VALADARES FILHO, S.C. et al. Degradação in vitro da fibra em detergente neutro de forragem tropical de baixa qualidade em função de suplementação com proteína e/ou carboidratos. Revista Brasileira de Zootecnia, v.37, p.494-503, 2008.

DelCURTO, T.; COCHRAN, R.C.; HARMON, D.L. et al. Supplementation of dormant Tallgrass-Prarie forage: I. Influence of varying supplemental protein and (or) energy levels on forage utilization characteristics of beef steers in confinement. Journal of Animal Science, v.68, p.515-531, 1990a.

DelCURTO, T.; COCHRAN, R.C.; CORAH, L.R. et al. Supplementation of dormant Tallgrass-Prarie forage: II. Performance and forage utilization characteristics in grazing beef cattle receiving supplements of different protein concentrations. Journal of Animal Science, v.68, p.532-542, 1990b.

DETMANN, E.; VALADARES FILHO, S.C.; HENRIQUES, L.T. et al. Estimação da digestibilidade dos carboidratos não-fibrosos em bovinos utilizando-se o conceito de entidade nutricional em condições brasileiras. Revista Brasileira de Zootecnia v.35, n.4, p.1479-1486, 2006a.

DETMANN, E.; VALADARES FILHO, S.C.; PINA, D.S. et al. Estimação da digestibilidade do extrato etéreo em ruminantes a partir dos teores dietéticos: desenvolvimento de um modelo para condições brasileiras. Revista Brasileira de Zootecnia. v.35, p.1469-1478, 2006b.

DETMANN, E.; PINA, D.S.; VALADARES FILHO, S.C. et al. Estimação da fração digestível da proteína bruta em dietas para bovinos em condições brasileiras. Revista Brasileira de Zootecnia, v.35, n.5, p.2101-2109, 2006c.

DETMANN, E.; PAULINO, M.F.; VALADARES FILHO, S.C. et al. Fatores controladores de consumo em suplementos múltiplos fornecidos ad libitum para bovinos manejados a pasto. Caderno Técnico de Veterinária e Zootecnia, v.55, p.73-93, 2007.

DETMANN, E.; PAULINO, M.F.; MANTOVANI, H.C. et al. Parameterization of ruminal fiber degradation in low-quality tropical forage using Michaelis-Menten kinetics. Livestock Science, v.126, p.136-146, 2009.

HANNAH, S.M.; COCHRAN, R.C.; VANZANT, E.S. et al. Influence of protein suplementation on site and extent of digestion, forage intake, and nutrient flow characteristics in steers consuming dormant Bluestem-Range forage. Journal of Animal Science, v.69, p.2624-2633, 1991.

HOOVER, W.H. Chemical factors involved in ruminal fiber digestion. Journal of Dairy Science, v.69, p.2755-2766, 1986.

KÖSTER, H.H.; WOODS, B.C.; COCHRAN, R.C. et al. Effects of increasing proportion of supplemental $\mathrm{N}$ from urea in prepartum supplements on range beef cow performance and forage intake and digestibility by steers fed low-quality forage. Journal of Animal Science, v.80, p.1652-1662, 2002.

LENG, R.A. Supplementation of tropical and subtropical pastures for ruminant production. In: GILCHRIST, F.M.C.; MACKIE, R.I. (Eds.) Herbivore nutrition in the subtropics and tropics. Craighall: The Science Press Ltd., 1984. p.129-144.

LENG, R.A. Factors affecting the utilization of "poor-quality" forages by ruminants particularly under tropical conditions. Nutritional Research Review, v.3, p.277-303, 1990.

LICITRA, G.; HERNANDEZ, T.M.; Van SOEST, P.J. Standardization of procedures for nitrogen fractionation of ruminant feeds.
Animal Feed Science and Technology, v.57, p.347-358, 1996.

MATHIS, C.P.; COCHRAN, R.C.; HELDT, J.S. et al. Effects of supplemental degradable intake protein on utilization of medium- to low-quality forages. Journal of Animal Science, v.78, p.224-232, 2001

McALLAN, A.B.; SMITH, R.H. Factors influencing the digestion of dietary carbohydrates between the mouth and abomasum of steers. British Journal of Nutrition, v.50, p.445-454, 1983.

MERTENS, D.R. Gravimetric determination of amylase-treated neutral detergent fiber in feeds with refluxing in beakers or crucibles: collaborative study. Journal of AOAC International, v.85, p.1217-1240, 2002.

NATIONAL RESEARCH COUNCIL - NRC. Nutrient requirements of dairy cattle. 6.ed. Washington, D.C.: Academic Press, 1988. 158p.

NATIONAL RESEARCH COUNCIL - NRC. Nutrient requirements of dairy cattle. 7.ed. Washington, D.C.: National Academic Press, 2001. 381p.

NOCEK, J.E.; RUSSELL, J.B. Protein and energy as an integrated system. Relation of ruminal protein and carbohydrates availability to microbial synthesis and milk production. Journal of Dairy Science, n.71, p.2070-2107, 1988.

ORTIZ-RUBIO, M.A.; ØRSKOV, E.R.; MILNE, J. et al. Effect of different sources of nitrogen on situ degradability and feed intake of Zebu cattle fed sugarcane tops (Saccharum officinarum). Animal Feed Science and Technology, v.139, p.143-158, 2007.

PAULINO, M.F.; FIGUEIREDO, D.M.; MORAES, E.H.B.K. et al. Suplementação de bovinos em pastagens: uma visão sistêmica. In: SIMPÓSIO DE PRODUÇÃO DE GADO DE CORTE, 4., 2004, Viçosa, MG. Anais... Viçosa, MG: SIMCORTE, 2004. p.93-144.

PAULINO, M.F.; DETMANN, E.; VALADARES FILHO, S.C. Suplementação animal em pasto: energética ou protéica? In: SIMPÓSIO SOBRE MANEJO ESTRATÉGICO DA PASTAGEM, 3., 2006, Viçosa, MG. Anais... Viçosa, MG: SIMFOR, 2006. p.359-392.

POPPI, D.P.; McLENNAN, S.R. Protein and energy utilization by ruminants at pasture. Journal of Animal Science, v.73, p.278-290, 1995.

RUSSELL, J. B.; O'CONNOR, J. D.; FOX, D.G. et al. A net carboidrate and protein system for evaluating cattle diets. I. Ruminal fermentation. Journal of Animal Science, v.70, n.11, p.3551-3561, 1992.

SAMPAIO, C.B. Consumo, digestibilidade e dinâmica ruminal em bovinos alimentados com forragem tropical de baixa qualidade suplementados com compostos nitrogenados. 2007. 53f. Dissertação (Mestrado em Zootecnia) - Universidade Federal de Viçosa, Viçosa, MG, 2007.

SAMPAIO, C.B.; DETMANN, E.; LAZZARINI, I. et al. Rumen dynamics of neurtal detergent fiber in cattle fed low-quality tropical forage and supplemented with nitrogenous compounds. Revista Brasileira de Zootecnia, v.38, p.560-569, 2009.

SATTER, L.D.; SLYTER, L.L. Effect of ammonia concentration on rumen microbial protein production in vitro. British Journal of Nutrition, v.32, p.199-208, 1974.

SILVA, D.J.; QUEIROZ, A.C. Análise de alimentos. Métodos químicos e biológicos. 3.ed. Viçosa, MG: Editora UFV, 2002. 235p.

USHIDA, K.; LASSALAS, B.; JOUANY, J.P. Determination of assay parameters for RNA analysis in bacterial and duodenal samples by spectrophotometry. Influence of treatment and preservation. Reproduction Nutrition Development, v.25, p.1037-1046. 1985.

VALADARES FILHO, S.C.; PINA, D.S.; CHIZZOTTI, M.L. et al. Degradação ruminal da proteína dos alimentos e síntese de proteína microbiana. In: VALADARES FILHO, S.C.; PAULINO, P.V.R.; MAGALHÃES, K.A. (Eds.) Exigências nutricionais de zebuínos e tabelas de composição de alimentos. Viçosa, MG: DZO-UFV, 2006. p.13-44. 
VAN SOEST, P.J. Nutritional ecology of the ruminant. 2.ed. Ithaca: Cornell University Press, 1994. 476p.

VERBIC, J.; CHEN, X.B.; MACLEOD, N.A. et al. Excretion of purine derivatives by ruminants. Effect of microbial nucleic acid infusion on purine derivative excretion by steers. Journal of Agricultural Science, v.114, p.243-248, 1990.
WALLACE, R.J.; ONODERA, R.; COTTA, M.A. Metabolism of nitrogen-containing compounds. In: HOBSON, R.J.; STEWART, C.S. (Eds.) The rumen microbial ecosystem. 2.ed. London: Blackie Academic \& Professional, 1997. p.283-328.

WHITE, D. The physiology and biochemistry of prokaryotes. 2.ed. New York: Oxford University Press, 2000. 565p. 